\title{
EKSEKUSI JAMINAN FIDUSIA DALAM KAJIAN UNDANG- UNDANG NOMOR 42 TAHUN 1999 TENTANG JAMINAN FIDUSIA
}

\author{
Soegianto \\ Magister Hukum, Universitas Semarang \\ Email : Soegianto@usm.ac.id \\ Diah Sulistiyani $R$ \\ Magister Hukum, Universitas Semarang \\ Muhammad Junaidi \\ Magister Hukum, Universitas Semarang
}

\begin{abstract}
Abstrak
Pelaksanaan eksekusi jaminan Fidusia selama ini masih banyak menggunakan jasa debt collector. Banyak permasalahan yang timbil dalam pelksanaan penggunaan jasa debt collector. Penelitian ini bertujuan untuk menganalisis kelemahan dalam pelaksanan eksekusi jaminan Fidusia. yang telah disebutkan sebelumnya yaitu, pelaksanaan eksekusi yang dilakukan kreditur melalui jasa debt collector kadangkala menimbulkan masalah baru antara kreditur dengan debitur. Penelitian ini menggunakan metode penelitian yuridis normatif. Hasil penelitian ini eksekusi jaminan Fidusia mempunyai kekuatan hukum mengikat yang sama dengan putusan pengadilan yang telah berkekuatan hukum tetap. Pelaksanaan eksekusi jaminan Fidusia masih banyak ditemukan permasalahan seperti mengeksekusi barang jaminan Fidusia dengan cara kekerasan, intimidasi bahkan dengan cara merampas barang jaminan Fidusia di jalan.

Kata kunci : Eksekusi; Jaminan; Fidusia.
\end{abstract}




\title{
EXECUTION OF FIDUSIAL GUARANTEE IN LAW NUMBER 42 OF 1999 CONCERNING FIDUSIAN GUARANTEE
}

\begin{abstract}
Abstarct
The execution of Fiduciary guarantees so far still uses many debt collector services. Many problems have occurred in the implementation of debt collector services. This study aims to analyze weaknesses in the implementation of Fiduciary guarantee execution. previously mentioned, namely, the execution of executions carried out by creditors through debt collector services sometimes creates new problems between creditors and debtors. This study uses normative juridical research methods. The result of this research is that the execution of the Fiduciary guarantee has the same binding legal force as a court decision that has permanent legal force. The execution of Fiduciary guarantees is still often found problems such as executing Fiduciary collateral by force, intimidation and even by seizing Fiduciary collateral on the road.

Keywords: Execution; Guarantee; Fiduciary.
\end{abstract}




\section{PENDAHULUAN}

\section{A. Latar belakang}

Salah satu prinsip yang ada pada negara hukum adalah tidak adanya main hakim sendiri. Persoalan-persoalan yang terjadi tentunya harus didasarkan dengan prinsip keadilan dan memberikan susuatunya sesuatu proporsinya. Kebutuhan dasar tindakan tidak main hakim sendiri akan mengarah pada aspek ketertiban dalam masyarakat.

Konsep rechtstaat bersumber dan rasio manusia, liberalistik individualistik, humanisme yang antroposentrik, pemisahan negara dan agama secara mutlak-ateisme dimungkinkan.50 Adapun unsurunsur utama menurut F. J. Stahl terdapat 4 (empat) unsur dan negara hukum, yakni: (1) Adanya jaminan terhadap hak asasi manusia; (2) adanya pembagian kekuasaan; (3) pemerintah harusah berdasarkan peraturan-peraturan hukum; dan (4) adanya peradilan administrasi. Sementara menurut Scheltema unsurunsurnya terdiri dan: (1) Kepastian Hukum; (2) Persamaan; demokrasi dan; (4) pemerintahan yang melayani kepentingan umum. ${ }^{1}$

Tidak dapat disangkal, bahwa pembangunan ekonomi negaranegara di berbagai sektornya, terutama kegiatankegiatan bisnis yang dilakukan para pelaku bisnis akan selalu diikuti oleh perkembangan kebutuhan dana melalui kredit, dan pemberian fasilitas kredit akan selalu membutuhkan adanya jaminan. Dibutuhkan jaminan dan agunan dalam suatu pemberian fasilitas kredit adalah semata-mata berorientasi untuk melindungi kepentingan kreditur, agar dana yang telah diberikannya kepada debitur dapat dikembalikan sesuai jangka

${ }^{1}$ Sirajuddin dan Winardi, 2015, Hukum Tata Negara Indonesia, Setara

Press(Kelompok Instras Publising), Malang, hlm 25 waktu yang ditentukan. Dengan perkataan lain, pihak pemilik dana (kreditor), terutama lembaga perbankan atau lembaga pembiayaan mensyaratkan adanya jaminan bagi pemberian kredit demi keamanan dana dan kepastian hukumnya. ${ }^{2}$

Jaminan mempunyai fungsi yang sangat penting dalam kegiatan ekonomi pada umumnya karena dalam pemberian pinjaman modal dari lembaga keuangan (baik bank maupun bukan bank) mensyaratkan adanya suatu jaminan, yang harus dipenuhi para pencari modal kalau ia ingin mendapatkan pinjaman/tambahan modal (berupa kredit) tersebut baik untuk jangka panjang maupun jangka pendek. ${ }^{3}$

Fidusia yang berarti penyerahan hak milik atas dasar kepercayaan memberikan kedudukan kepada debitur untuk tetap menguasai barang jaminan, walaupun hanya sebagai peminjam pakai untuk sementara waktu atau tidak lagi sebagai pemilik. Apalagi lembaga fidusia ini dikaitkan dengan ketentuan Pasal 1152 KUH Perdata memang tampaknya sangat bertentangan, karena menurut ketentuan Pasal tersebut mengharusakan barang jaminan diserahkan secara fisik kepada pemberi kredit. Ketentuan Pasal 1152 KUH Perdata menyatakan, bahwa : "Jika barang jaminan tetap dibiarkan dikuasai debitur maka jaminan tersebut akan tidak sah”. ${ }^{4}$

\footnotetext{
${ }^{2}$ Debora R.N.N. Manurung, Perlindungan Hukum Debitur Terhadap ParateEksekusi Obyek Jaminan Fidusia, ,Jurnal Ilmu Hukum Legal Opinion Edisi 2 Volume 3, 2015, Palu, Universitas Tadulako, hlm 1-2.

${ }^{3}$ Jatmiko Winarno, Perlindungan Hukum Bagi Kreditur Melalui Perjanjian Jaminan Fidusia, Jurnal Independent, 2013, Lamongan, Universita Islam Lamongan, hlm 44.

${ }^{4}$ Sri Ahyani, Perlindungan Hukum Bagi Kreditur Pada Perjanjian Jaminan Fidusia, Jurnal Yuridika Vol 24 No 1, 2011,
} 
Pelaksanaan eksekusi jaminan fidusia diatur dalam Pasal 29 Undang-Undang Nomor 42 Tahun 1999 tentang Jaminan Fidusia yang menyatakan bahwa pelaksanaan eksekusi jaminan fidusia dapat dilakukan dengan cara pelaksanaan titel eksekutorial, penjualan melalui pelelangan umum, atau penjualan di bawah tangan dengan persetujuan kedua belah pihak, namun dalam prakteknya terkadang ketika akan melakukan eksekusi terhadap jaminan fidusia pada salah satu debitur, jaminan tersebut ternyata telah beralih dan dikuasai oleh pihak ketiga tanpa persetujuan dari pihak bank. $^{5}$

Salah satu persoalan yang acapkali muncul terjadinya adalah tindakan main hakim sendiri dalam penyelesaian sengketa jaminan fidusia. Eksekusi dalam penyelesaian jaminan fidusia menjadikonflik baru yang timbul mengingat terdapat dilema penafsiran yang bermuara pada ketidakpastian hukum yang terjadi. Undang-Undang Republik Indonesia Nomor 42 Tahun 1999 Tentang Jaminan Fidusia dinyatakan bahwa dalam pasla 1 ayat 2 bahwa Jaminan Fidusia adalah hak jaminan atas benda bergerak baik yang berwujud maupun yang tidak berwujud dan benda tidak bergerak khususnya bangunan yang tidak dapat dibebani hak tanggungan sebagaimana dimaksud dalam Undang-undang Nomor 4 Tahun 1996 tentang Hak Tanggungan yang tetap berada dalam penguasaan

Bandung, Sekolah Tinggi Ilmu Hukum Bandung, hlm 308-309.

${ }^{5}$ Setia Budi, Permohonan Eksekusi

Kepada Pengadilan Negeri Berkaitan

Dengan Perjanjian Fidusia Terhadap

Jaminan Yang Digelapkan, Jurnal

Cendekia Hukum Vol 3 No 1, 2013,

Payakumbuh, STIH Putri Maharaja

Payakumbuh, hlm 100.
Pemberi Fidusia, sebagai agunan bagi pelunasan utang tertentu, yang memberikan kedudukan yang diutamakan kepada Penerima Fidusia terhadap kreditor lainnya. Pasal 4 sendiri dinyatakan bahwa Jaminan Fidusia merupakan perjanjian ikutan dan suatu perjanjian pokok yang menimbulkan kewajiban bagi para pihak untuk memenuhi suatu prestasi.

Pengaturan fidusia di atas tentunya memberikan jaminan hukum yang jelas terkait adanya persoalan-persoalan yang terjadi dalam praktik pelaksanaan jaminan fidusia. Namun dalam faktanya, masih banyak terjadi persoalanpersoalan dari tindakan main hakim sendiri yang terjadi apabila salah satu pihak melakukan wanprestasi.

$\begin{array}{crr}\text { Di } & \text { sinilah } & \text { pentingnya } \\ \text { dilakukan } & \text { kajian } & \text { secara }\end{array}$ komperhensif terhadap pelaksanaan jaminan fidusia utamanya pada masalah eksekusi sehingga tidak menimbulkan masalah. Di samping itu tujuan dan manfaat dari kajian ini akan membuka kelemahan subtansi hukum dan bagaimana nantinya dapat menyelesaikan masalahmasalah yang ada.

\section{PEMBAHASAN}

\section{A. Pelaksanaan Ekseskusi Jaminan} Fidusia

Praktik esksekusi jaminan fidusia, perlu diperhatikan sebenarnya bahwa pada umumnya perusahaan atau lembaga pembiayaan di dalam melaksanakan penjualan atas barang bergerak tersebut kepada konsumen dengan menggunakan perjanjian yang mengikutkan adanya jaminan fidusia bagi objek benda jaminan fidusia berupa Bukti Pemilik Kendaraan Bermotor (BPKB), akan tetapi ternyata dalam prakteknya banyak dari perjanjian yang dibuat oleh perusahaan tersebut tidak dibuat dalam Akta Notariil (Akta Notaris) 
dan tidak didaftarkan di Kantor Pendaftaran Fidusia untuk mendapat sertifikat Akta yang memuat irahirah "Demi Keadilan Berdasarkan Ketuhanan Yang Maha Esa." walaupun secara tertulis lembaga pembiayaan tersebut dalam melakukan perjanjian pembiayaan mencantumkan kata-kata dijaminkan secara fidusia ${ }^{6}$.

\section{Lembaga pembiayaan}

menyediakan barang bergerak yang diminta konsumen (semisal motor atau mesin industri) kemudian diatasnamakan konsumen sebagai debitur (penerima kredit/ pinjaman). Konsekuensinya debitur menyerahkan kepada kreditur (pemberi kredit) secara fidusia. Artinya, debitur sebagai pemilik atas nama barang menjadi pemberi fidusia kepada kreditur yang dalam posisi sebagai penerima fidusia. Praktek sederhana dalam jaminan fidusia adalah debitur/pihak yang punya barang mengajukan pembiayaan kepada kreditor, lalu kedua belah sama-sama sepakat mengunakan jaminan fidusia terhadap benda milik debitor. ${ }^{7}$

Berdasarkan ketentuan Pasal 14 ayat (3) UU No. 42 Tahun 1999 tentang Jaminan Fidusia (UUJF), jaminan fidusia baru lahir pada tanggal yang sama dengan tanggal dicatatnya jaminan Fidusia dalam Buku Daftar Fidusia. kemudian Pasal 15 ayat (1) UU No. 42 Tahun 1999 tentang Jaminan Fidusia : "Dalam Sertifikat Jaminan $F$ idusia

\footnotetext{
${ }^{6}$ Alfian, Eksekusi Objek Jaminan Fidusia Dalam Kontrak Pembiayaan Konsumen Di Kota Palu, e Jurnal

Katalogis, Volume 5 Nomor 1Januari 2017 hlm 14

7 Fandy Ahmad, Keabsahan Kuasa Untuk Menandatangani Akta Oleh LembagaPembiayaan Jaminan Fidusia Suatau Kajian Peraturan Pemerintah Nomor 21 Tahun 2015, Jurnal Ius Constituendum Volume 3 No 2, 2018, Semarang, Magister Hukum Pasca Sarjana Universitas Semarang. hlm 149.
}

sebagaimana dimaksud dalam Pasal 14 ayat (1) dicantumkan katakata "Demi Keadilan Berdasarkan Ketuhanan Yang Maha Esa". Selanjtnya Pasal 15 ayat (2) UU No. 42 Tahun 1999 tentang Jaminan Fidusia : "Sertifikat Jaminan Fidusia sebagaimana dimaksud dalam ayat (1) mempunyai kekuatan eksekutorial yang sama dengan putusan pengadilan yang telah memperoleh kekuatan hukum tetap." Pasal 15 ayat (3) UU No. 42 Tahun 1999 tentang Jaminan Fidusia : "Apabila debitor cidera janji, Penerima Fidusia mempunyai hak menjual Benda yang menjadi objek Jaminan Fidusia atas kekuasaannya sendiri." 8

Di samping itu putusan pengadilan yang mempunyai titel eksekutorial adalah putusan yang bersifat atau yang mengandung amar "condemnatoir", sedangkan putusan Pengadilan yang bersifat deklaratoir dan konstitusif tidak dilaksanakan eksekusi karena tidak memerlukan eksekusi dalam menjalankannya. Oleh karenanya, eksekusi pada hakekatnya tidak lain ialah realisasi daripada kewajiban pihak yang kalah untuk memenuhi prestasi yang tercantum dalam putusan pengadilan tersebut. Pihak yang menang dapat memohon eksekusi pada pengadilan yang memutus perkara tersebut untuk melaksanakan putusan tersebut secara paksa (execution force). ${ }^{9}$

Hal ini menjadi salah satu bentuk kultur hukum yang tidak dapat dikesampingkan. Kultur hukum merupakan salah satu unsur dan sistem hukum yang membicarakan hal-hal sebagaimana dikemukakan di atas. Ia melihat, bahwa hukum itu tidak layak hanya

\footnotetext{
${ }^{8}$ Ibid, hlm 15

Abdul Ghoni, Implementasi Penyelesaian Hukum Atas Eksekusi Jaminan Dalam Perbankan Syariah, Jurnal Ius Constituendum Volume 1 No 2, 2016, Semarang, Magister Hukum Pasca Sarjana Universitas Semarang. hlm 68.
} 
dibicarakan dan segi struktur dan substansinya saja, melaink an juga dan segi kulturnya (Friedman, 1977:6-9). Struktur hukum adalah pola yang mempenlihatkan tentang bagaimana hukum itu dijalankari menurut ketentuan-ketentuan formalriya. Struktun mi memperlihatkan bagaimana pengadilan. pembuatan hukum dan lain-lain badan serta proses hukum itu berjalan dan dijalankan. Substansi hukum adalah peraturanperaturan yang dipakai oleh para pelaku hukum pada waktu melakukan perbuatan-perbuatan senta hubungan-hubungan hukum. Pada waktu pedagang melakukan penjanjian antara sesamanya, pada waktu itu ia mendasarkan hubungannya kepada peraturanperaturan di bidang perdagangan dan peraturan inilah yang disebut sebagai substansi hukum ${ }^{10}$.

Proses eksekusi lembaga Jaminan Fidusia emungkinkan kepada para pemberi fidusia untuk menguasai benda yang dijaminkan,untuk melakukan kegiatan usaha yang dibiayai dari pinjaman dengan menggunakan jaminan fidusia. Pada awalnya, benda yang menjadi obyek fidusia terbatas pada kekayaan benda bergerak yang berwujud dalam bentuk peralatan. Akan tetapi dalam perkembangan selanjutnya, benda yang menjadi obyek fidusia termasuk juga kekayaan benda bergerak yang tak berwujud, maupun benda tak bergerak. Pelaksanaan pembiayaan antara kreditur dan debitur, kadangkala terjadi wanprestasi atau ingkar janji. Maka, ketika debitur ingkar janji pihak kreditur bisa melakukan eksekusi benda yang sudah dijaminkan melalui jaminan fidusia. Menurut Subekti, yang dimaksud dengan eksekusi adalah upaya dari pihak

\footnotetext{
${ }^{10}$ Sadjipto Rahardjo, 1982, Ilmu Hukum, Alumni, Bandung, hlm 168
}

yang dimenangkan dalam putusan guna mendapatkan yang menjadi haknya dengan bantuan kekuatan hukum, memaksa pihak yang dikalahkan untuk melaksanakan putusan6 ${ }^{11}$.

Debitur yang ingkar janji, maka kreditur bisa langsung mengeksekusi

benda jaminan yang dijaminkan fidusia. Karena di dalam sertifikat jaminan fidusia memuat ketentuan kata-kata " DEMI KEADILAN BERDASARKAN KETUHANAN YANG MAHA ESA". Dengan katakata ini, maka mempunyai kekuatan hukum seperti keputusan pengadilan. Hal ini sesuai dengan UndangUndang Nomor 42 tahun 1999 tentang Jaminan Fidusia yang menyatakan, apabila debitor atau pemberi fidusia cidera janji, eksekusi terhadap benda yang menjadi obyek jaminan fidusia dapat dilakukan de ngan cara : (1)Pelaksanaan titel eksekutorial oleh penerima fidusia (2)Penjualan benda yang menjadi obyek jaminan fidusia atas kekuasaan penerima fidusia sendiri melalui pelelangan umum serta mengambil pelunasan piutangnya dari hasil penjualan (3)Penjualan di bawah tangan yang dilakukan berdasarkan kesepakatan pemberi dan penerima fidusia jika dengan cara demikian dapat diperoleh harga tertinggi yang menguntungkan para pihak. Pelaksanaan penjualan di dawah tangan dilakukan setelah lewat waktu 1 (satu) bulan sejak diberitahukan secara tertulis oleh pemberi dan atau penerima fidusia kepada pihak-pihak yang

\footnotetext{
${ }^{11}$ Junaidi Abdullah, Jaminan Fidusia (Tata Cara Dan Pendaftaran Eksekusi) Jurnal Bisnis dan Manajemen Islam, Vol. 4, No. 2, Desember 2016, Padang, UIN Imam Bonjol, hlm 217
} 
berkepentingan dan diumumkan sedikitnya dalam 2 (dua) surat kabar yang beredar di daerah yang bersangkutan. Undang-undang jaminan fidusia juga diterangkan, bahwa pemberi fidusia wajib menyerahkan benda yang obyek jaminan fidusia dalam rangka pelaksanaan eksekusi jaminan fidusia. $^{12}$

Benda yang obyek jaminan fidusia terdiri atas benda perdagangan atau efek yang dapat dijual di pasar atau di bursa, penjualannya dapat dilakukan di tempat- tempat tersebut sesuai dengan peraturan perundangundangan yang berlaku. Setiap janji untuk melaksanakan eksekusi terhadap benda yang menjadi obyek jaminan fidusia dengan cara yang bertentangan dengan ketentuan di atas maka batal demi hukum. Setiap janji yang memberikan kewenangan kepada penerima fidusia untuk memiliki benda yang menjadi obyek jaminan fidusia apabila debitor cidera janji, batal demi hukum. Jika eksekusi melebihi nilai penjaminan, penerima fidusia wajib mengembalikan kelebihan tersebut kepada pemberi fidusia. Apabila hasil eksekusi tidak mencukupi untuk pelunasan utang, debitor tetap bertanggung jawab atas utang yang belum terbayar. Akan tetapi, pelaksanaan eksekusi yang dilakukan kreditur melalui jasa debt collector kadangkala menimbulkan masalah baru antara kreditur dengan debitur. Hal ini dikarenakan cara debt collector dalam mengeksekusi barang jaminan fidusia dengan cara kekerasan, intimidasi bahkan dengan cara merampas barang jaminan fidusia dijalan, hal inilah yang menimbulkan perlawanan dari pihak debitur ${ }^{13}$.

Tentunya hak tersebut menjadi permasalahan. Terlebih juga tidak sesuai dengan prinsip negara hukum. Fuller mengajukan satu pendapat untuk mengukur apakah kita pada suatu saat dapat berbicara mengenai adanya suatu sistem hukum. Ukuran tersebut diletakannya pada delapan azas yang dinamakannya principles of legality, yaitu:

1. Suatu sistem hukum harus mengandung peraturanpperaturan. Yang dimaksud di sini adalah, bahwa ia tidak boleh mengandung sekedar keputusan-keputusa nd yang bersifat ad hoc.

2. Peraturan-peraturan yang telah dibuat itu harus diumumkan.

3. Tidak boleh ada peraturan yang berlaku surut, oleh karena apabila yang demikian itu tidak ditolak, maka peraturan itu tidak bisa dipakai untuk menjadi pedoman tingkah laku. Membolehkan pengaturan secara berlaku surut berarti merusak integritas peraturan yang ditujukan untukberlaku bagi waktu yang akan datang.

4. Peraturan-peraturan harus disusun dalam rumusan yang bisa dimengerti

5. Suatu sistem tidak boleh mengandung peraturanp peraturan yang bertentangan satu sama lain.

12 Ibid., 
6. Peraturan-peraturan tidak boleh mengandung tuntutan yang melebihi apa yang dapat dilakukan.

7. Tidak boleh ada kebiasaan untuk sering merubahr ubah peraturan sehingga menyebabkan seorang akan kehilangan orientasi

8. Harus ada kecocokan antara peraturan yang diundangkan dengan pelaksanaannya sehari-hari. $^{14}$

Untuk itu, kepolisian membuat keputusan melalui Peraturan Kepala Kepolisian Negara Indonesia Nomor 8 tahun 2011 tentang Pengamanan Eksekusi Jaminan Fidusia. Eksekusi jaminan fidusia mempunyai kekuatan hukum mengikat yang sama dengan putusan pengadilan yang telah berkekuatan hukum tetap, sehingga memerlukan pengamanan dari Kepolisian Negara Republik Indonesia. Yang dimaksud dengan Pengamanan Eksekusi adalah tindakan kepolisian dalam rangka memberi pengamanan dan perlindungan terhadap pelaksana eksekusi, pemohon eksekusi, termohon eksekusi (tereksekusi) pada saat eksekusi dilaksanakan. Tujuan peraturan ini meliputi : (1)Terselenggaranya pelaksanaan eksekusi jaminan Fidusia secara aman, tertib, lancar, dan dapat dipertanggungjawabkan

(2)Terlindunginya keselamatan dan keamanan Penerima Jaminan Fidusia, Pemberi Jaminan Fidusia, dan/atau masyarakat dari perbuatan yang dapat menimbulkan kerugian harta benda dan/atau keselamatan

${ }^{14}$ Sadjipto Rahardjo, 1982, Ilmu Hukum, Alumni, Bandung, hlm 92. jiwa. Objek pengamanan jaminan fidusia, meliputi hak jaminan atas : (1)Benda bergerak yang berwujud (2)Benda bergerak yang tidak berwujud; dan (3)Benda tidak bergerak khususnya bangunan yang tidak dapat dibebani hak tanggungan ${ }^{15}$.

Namun terlepas dari kepastian yang ad atersebut tetap kelemahankelemahan yang terjadi ada, baik dari sisi praktis maupun sisi teoritisnya. Oleh karenanya upaya untuk mengatasi masalah-masalah hukum yang ada melalui pengaturan yang jelah menjadi salah satu solusi yang harus dijalankan dengan sedemikian rupa.

B. Kelemahan dan solusi atas
masalah pengaturan eksekusi
jaminan fidusia yang ada
utamanya dalam Undang-
Undang Republik Indonesia
Nomor 42 Tahun 1999
Tentang Jaminan Fidusia
Penjelasan UU jaminan Fidusia ditegaskan bahwa Jaminan Fidusia telah digunakan di Indonesia sejak zaman penjajahan Belanda sebagai suatu bentuk jaminan yang lahir dari yurisprudensi. Bentuk jaminan ini digunakan secara luas dalam transaksi pinjam-meminjam karena proses pembebanannya dianggap sederhana,mudah, dan cepat, tetapi tidak menjamin adanya kepastian hukum.

Pelaksanaan praktik fidusia, seperti telah dijelaskan bahwa Jaminan Fidusia memberikan kemudahan bagi para pihak yang menggunakannya, khususnya bagi Pemberi Fidusia. Namun sebaliknya karena Jaminan Fidusia tidak

15 Ibid. 
didaftarkan, kurang menjamin kepentingan pihak yang menerima fidusia, Pemberi Fidusia mungkin saja menjaminkan benda yang telah dibebani dengan fidusia kepada pihak lain tanpa sepengetahuan Penerima Fidusia.

Sebelum Undang-undang ini dibentuk, pada umumnya benda yang menjadi obyek Jaminan Fidusia adalah benda bergerak yang terdiri dari benda dalam persediaan (inventory), benda dagangan,piutang, peralatan mesin, dan kendaraan bermotor. Oleh karena itu, guna memenuhi kebutuhan masyarakat yang terus berkembang, maka menurut Undang-undang ini obyek Jaminan Fidusia diberikan pengertian yang luas yang luas yaitu benda bergerak yang berwujud maupun tak berwujud, dan benda tak bergerak yang tidak dapat dibebani dengan hak tanggungan sebagaimana ditentukan dalam Undang-undang Nomor 4 Tahun 1996 tentang hak Tanggungan.

Dalam pratiknya, terdapat kelemahan yang telah disebutkan sebelumnya yaitu, pelaksanaan eksekusi yang dilakukan kreditur melalui jasa debt collector kadangkala menimbulkan masalah baru antara kreditur dengan debitur. Hal ini dikarenakan cara debt collector dalam mengeksekusi barang jaminan fidusia dengan cara kekerasan, intimidasi bahkan dengan cara merampas barang jaminan fidusia dijalan, hal inilah yang menimbulkan perlawanan dari pihak debitur.

Meskipun dalam praktiknya sudah diatur dalam Peraturan Kepala Kepolisian Negara Indonesia Nomor 8 tahun 2011 tentang
Pengamanan Eksekusi Jaminan Fidusia. Namun masih menjadi catatan penting bahwa maslaah pokok cara debt collector dalam mengeksekusi barang jaminan fidusia dengan cara kekerasan, intimidasi bahkan dengan cara merampas barang jaminan fidusia dijalan, masih menjadi bagian momok tersendiri yang tidak dapat dipisahkan dalam praktik eksekusi jaminan fidusia.

Disinilah yang diatur bukan lagi proses eksekusinya akan tetapi ketaatan perusahaan dalam menjalankan eksekusi. Perusahaan dalam ketentuan UU jaminan Fidusia harus diarahkan untuk taat asas hukum yang baik dan benar bukan hanya sekedar mengalihfungsikan tanggung jawab pada keanggotaan perusahaan dan pertanggung jawaban kemudian beralih pada anak buah. Hal ini menjadi masalah pokok selama ini.

Disamping itu maslaah pokok yang lain adalah kesadaran hukum perusahaan. Apabila ditilik dari proses perkembangan hukum dalam sejarah terhadap hubungan dengan eksistensi dan peranan dari kesadaran hukum masyarakat dalam tubuh hukum positif, terdapat suatu proses pasang surut dalam bentangan waktu yang teramat panjang. Peranan tersebut dapat dibagi dalam beberapa kelompok berikut :

a. Hukum masyarakat primitif secara total merupakan penjelmaan dari kesadaran hukum masyarakatnya. Kitab Undang-undang dipercaya sebagai penjelmaan dari kehendak dan kepercayaanan 
masyarakat tentang perbuatan baik atau buruk.

b. Paham Scholastic, percaya bahwa hukum berasal dari perintah Tuhan (Abad pertengah- an). Dalam hal ini kesadaran tidak penting bagi hukum, yang terpenting adalah titah Tuhan

c. Mahzab hukum alam moderen (abad ke-18 dan ke-19), percaya bahwa hukum merupakan hasil renungan manusia dengan menggunakan rasionya

d. Paham sosiologi (akhir abad ke-19 dan awal abad ke-20). Kesadaran hukum masyarakat berperan dalam pembentukan, penerapan, dan penganalisisan hukum ${ }^{16} 11$.

Hal yang demikian tentunya perlu direspon melalui adanya perubahan pola penegakan hukum yang menempatkan budaya hukum dapat ditekankan sebagai wujud mereaktivasi kembalinya programprogram yang sifatnya bersinergi terkait eksekusi dalam penerapan jaminan fidusia. Disinilah pola sosialisasi harus dijalankan terus menerus agar pelaksanaan jaminan fidusia dalam proses eksekusi dapat terlaksana dengan baik.

Prinsipnya kesadaran hukum pada masyarakat bukanlah merupakan proses yang sekali jadi, melainkan merupakan suatu rangkaian proses yang terjadi tahap demi tahap sebagai berikut :

1. Tahap pengetahuan hukum Dalam hal ini, merupakan

${ }^{16}$ Munir Fuady. Sosiologi Hukum Kontemporer, Interaksi Kekeuasaan, Hukum, dan Masyarakat (Bandung : Citra Aditya Bakti, 2007), hlm. 80. pengetahuan seseorang berkenaan dengan perilaku tertentu yang diatur oleh hukum tertuluis, yakni tentang apa yang dilarang atau apa yang dibolehkan

2. Tahap pemahaman hukum Yang dimaksud adalah bahwa sejumlah informasi yang dimiliki seseorang mengenai isi dari aturan hukum (tertulis), yakni mengenai isi, tujuan, dan manfaat dari peraturan tersebut.

3. Tahap sikap hukum (legal attitude) Merupakan suatu kecenderungan untuk menerima atau menolak hukum karena adanya penghargaan atau keinsyafan bahwa hukum tersebut bermanfaat atau tidak bermanfaat bagi kehidupan manusia. Dalam hal ini sudah ada elemen apresiasi terhadap aturan hukum.

4. Tahap Pola Perilaku Hukum Yang dimaksud adalah tentang berlaku atau tidaknya suatu aturan hukum dalam masyarakat. Jika berlaku suatu aturan hukum, sejauh mana berlakunya dan sejauh mana masyarakat mematuhinya ${ }^{17}$.

\section{PENUTUP}

Kepolisian membuat keputusan melalui Peraturan Kepala Kepolisian Negara Indonesia Nomor 8 tahun 2011 tentang Pengamanan 
Eksekusi Jaminan Fidusia. Eksekusi jaminan fidusia mempunyai kekuatan hukum mengikat yang sama dengan putusan pengadilan yang telah berkekuatan hukum tetap, sehingga memerlukan pengamanan dari Kepolisian Negara Republik Indonesia. Yang dimaksud dengan Pengamanan Eksekusi adalah tindakan kepolisian dalam rangka memberi pengamanan dan perlindungan terhadap pelaksana eksekusi, pemohon eksekusi, termohon eksekusi (tereksekusi) pada saat eksekusi dilaksanakan. Tujuan peraturan ini meliputi : (1)Terselenggaranya pelaksanaan eksekusi jaminan Fidusia secara aman, tertib, lancar, dan dapat dipertanggungjawabkan

(2)Terlindunginya

keselamatan dan keamanan Penerima Jaminan Fidusia, Pemberi Jaminan Fidusia, dan/atau masyarakat dari perbuatan yang dapat menimbulkan kerugian harta benda dan/atau keselamatan jiwa. Objek pengamanan jaminan fidusia, meliputi hak jaminan atas : (1)Benda bergerak yang berwujud (2)Benda bergerak yang tidak berwujud; dan (3)Benda tidak bergerak khususnya bangunan yang tidak dapat dibebani hak tanggungan.

Dalam pratiknya, terdapat kelemahan yang telah disebutkan sebelumnya yaitu, pelaksanaan eksekusi yang dilakukan kreditur melalui jasa debt collector kadangkala menimbulkan masalah baru antara kreditur dengan debitur. Hal ini dikarenakan cara debt collector dalam mengeksekusi barang jaminan fidusia dengan cara kekerasan, intimidasi bahkan dengan cara merampas barang jaminan fidusia dijalan, hal inilah yang menimbulkan perlawanan dari pihak debitur. Meskipun dalam praktiknya sudah diatur dalam Peraturan Kepala Kepolisian Negara Indonesia Nomor 8 tahun 2011 tentang Pengamanan Eksekusi Jaminan Fidusia. Namun masih menjadi catatan penting bahwa masalah pokok cara debt collector dalam mengeksekusi barang jaminan fidusia dengan cara kekerasan, intimidasi bahkan dengan cara merampas barang jaminan fidusia dijalan, masih menjadi bagian momok tersendiri yang tidak dapat dipisahkan dalam praktik eksekusi jaminan fidusia.

\section{Daftar Pustaka}

\section{Buku}

Alfian, Eksekusi Objek Jaminan Fidusia Dalam Kontrak Pembiayaan Konsumen Di Kota

Munir Fuady. Sosiologi Hukum Kontemporer, Interaksi Kekeuasaan, Hukum, dan Masyarakat, 2007, Bandung, Citra Aditya Bakti.

Sadjipto Rahardjo, 1982, Ilmu Hukum, Alumni, Bandung.

Sirajuddin dan Winardi, 2015, Hukum Tata Negara Indonesia, Setara Press(Kelompok Instras Publising), Malang.

\section{Jurnal}

Abdul Ghoni, Implementasi Penyelesaian Hukum Atas Eksekusi 
Jaminan Dalam Perbankan Syariah, Jurnal Ius Constituendum Volume 1 No 2, 2016, Semarang, Magister Hukum Pasca Sarjana Universitas Semarang.

Debora R.N.N. Manurung, Perlindungan Hukum Debitur Terhadap ParateEksekusi Obyek Jaminan Fidusia, ,Jurnal Ilmu Hukum Legal Opinion Edisi 2 Volume 3, 2015, Palu, Universitas Tadulako.

Fandy Ahmad, Keabsahan Kuasa Untuk Menandatangani Akta Oleh Lembaga Pembiayaan Jaminan Fidusia Suatau Kajian Peraturan Pemerintah Nomor 21 Tahun 2015, Jurnal Ius Constituendum Volume 3 No 2, 2018, Semarang, Magister Hukum Pasca Sarjana Universitas Semarang.

Jatmiko Winarno, Perlindungan

Hukum Bagi Kreditur Pada Perjanjian Jaminan Fidusia, Jurnal Independent, 2013, Lamongan, Universita Islam Lamongan. Junaidi Abdullah, Jaminan

Fidusia Di Indonesia (Tata cara Pendaftaran Dan Eksekusi) Jurnal Bisnis dan Manajemen Islam Vol. 4, No. 2, 2016, Padang, UIN Imam Bonjol.

Setia Budi, Permohonan Eksekusi Kepada Pengadilan Negeri Berkaitan Dengan Perjanjian Fidusia Terhadap Jaminan Yang Digelapkan, Jurnal Cendekia Hukum Vol 3 No 1, 2013, Payakumbuh, STIH Putri Maharaja Payakumbuh.

Sri Ahyani, Perlindungan Hukum Bagi Kreditur Pada Perjanjian Jaminan Fidusia, Jurnal Yuridika Vol 24 No 1, 2011, Bandung, Sekolah Tinggi Ilmu Hukum Bandung. 